\title{
GEREFORMEERDE KERKBEGRIP EN \\ KERKLIDMAATSKAP
}

Prof. B. Spoelstra

Hierdie onderwerp kan baie dieper teologies ontleed word as wat in hier die artikel gedoen word. Ons wil die kerkbegrip slegs oorsigtelik belig om aan te toon dat in die hantering van begrippe soos "lidmaatskap" invloed uit die Rasionalisme die Skriftuurlike kerkbegrip van die Gereformeerde Belydenis verduister het.

\section{INLEIDING}

Ek meen dat dr. A. Kuyper vir die eerste keer onderskei het tussen die kerk as instituut en die kerk as organisme. Met so 'n onderskeiding word 'n wonderlike werklikheid soos die kerk reeds ingedwing in vooropgestelde menslike kategorië van instituut en organisme. Kuyper het toe voorgestel dat die instituut die "georganiseerde" kerk sal wees, ampsdraers, kerkraad, meerdere vergaderings, eredienste ens. Die gelowiges of Christene sou dan kerk as organisme wees en hulleself in allerlei Christelike verenigings moes organiseer. Wanneer daar vandag van "kerk" gepraat word, word gewoonlik nie aan die "gelowiges" gedink nie, maar slegs in terme van instituut, struktuur of "ampsdraers".

In die omgangstaal is die verwarring selfs groter. Ons praat van "kerk bou" en dan is kerk ' $n$ gebou; daar word gevra na "die kerk se standpunt oor dans" en dan is die kerk iets soos 'n party, of groep; die koerante gee die "kerk" se standpunt weer en haal daarvoor dominees aan, alwaar die woord "dominee" beteken; dominees en teoloë praat van die "kerk se taak teenoor (sy?) jeug", die "kerk se kategese" of "kerk se prediking", waar "kerk" weer iets soos dominee moet beteken.

Dit is duidelik dat die gelowiges in hierdie snraakgebruik die voorwerp van die kerk en nie die kerk self uitmaak nie.

\section{VERWARRING TOT IN NUWE AFRIKAANSE BYBELVERTALING}

Die nuwe Afrikaanse Bybelvertaling (NAV) vertaal die Bybelse woord ekklessia soms met kerk (bv. Matt. 16:18) en dan weer met gemeente (bv. Matt. 18:17). Die vraag is: Waarom? Die antwoord is dat die begrip wat in die Bybel voorkom nie meer deur Westerse vertalers verdiskonteer kan word nie. In plaas van om ons kerkbegrip in ooreenstemming met die Bybel en Belydenis te bring, word die NAV aangepas by ons moderne verworde kerkbegrip.

Die Skrif kan ekklessia (uitgeroeptes) gebruik vir die een heilige algemene kerk of liggaam van Christus sowel as vir die gemeente op ' $n$ bepaalde plek, omdat die kerk in die Bybel altyd mense, gelowiges en nooit 'n struktuur, vereniging of instituut in eie reg is nie. Die kerk is 'n organisme van mense met ordelike en geordende karaktertrekke sodat dit met 'n liggaam of tempel vergelyk kan word. Die institusionele opset is egter beperk tot die dienste wat 
die Here gegee (geïnstitueer) het (vgl. 1 Kor. $12: 28$; Ef $4: 11$ v) en gaan die sigbare kerk vooraf. Immers hoe kan gelowiges 'n kerk (gemeente) in Christus word, indien daar nie eers bediening van die Woord was nie (Rom. 10:14)? Hierdie dienste is gegee (geïnstitueer ten behoewe van die gelowiges wat opgebou word in geloof (Ef. 4: $12 \mathrm{v}$ ), maar eenheid in geloof en nie organisasie nie, bepaal die wese van die kerk.

Die NAV pas by die Rasionalisme aan en gebruik twee verskillende woorde vir wat in die Bybel een begrip, soms in universele en soms in lokale $\sin$ is.

\section{ROOMSE INVLOED OP DIE KERKBEGRIP}

Hoewel die Reformatore ingrypend van Rome verskil, veral waar Calvyn die dienste aan die plaaslike kerk en aan bodiening van die Woord bind, moet ons raaksien en waardeer dat Rome steeds die dienste (ampte) as die institusionele opset van die kerk beskou het. Die Pous is die Stedehouer van Christus op aarde omdat hy die diens van biskop van Rome beklee. Daarom is kerk en koninkryk vir Rome dieselfde. Die "kerk" is vir Rome dus ook nie 'n instituut in eie reg buite die hiërargie nie, maar 'n priesterinstituut of regeergebied onder gesag van die pous. Die gelowiges word egter as "leke" ten opsigte van die "kerk" wat hulle moet versorg, beskou.

Wanneer koerante, dominees en teoloë vandag graag praat van die "kerk se taak" teenoor lidmate verraai dit ongetwyfeld invloed van hierdie Roomse beskouing.

\section{LUTHERSE INVLOED OP DIE KERKBEGRIP}

Luther het sterk positiewe invloed op die kerkbegrip uitgeoefen omdat hy die algemene priesterskap van die gelowiges teenoor die priesterskap van die Roomse clerus beklemtoon het. In beginsel kon enige gelowige enige kerklike diens vervul. Daarby het hy weer sterker by die Bybelse ekklessia aangesluit.

Luther kon egter nie die sigbare en onsigbare gestaltes van die een kerk, die liggaam van Christus, duidelik maak nie. Vanweë sy twee-rvke leer het hy dit voorgestel asof die kerk van ware gelowiges deur God self in die hemelregime geken en verwesenlik word. Ten behoewe daarvan moet die aardse ryk of regering wat aan die vors toevertrou is, ' $n$ preekinstituut inrig om die Woord te bedien wat die Gees gebruik. Die sigbare kerkorganisasie is dus van totaal ander orde as die eintlike onsigbare kerk wat deur geloof benaal word en gaan uit van die vors wat predikante voorsien en deur konsistories kontroleer.

Hierdie opvatting het groot invloed in Suid-Afrika gehad. Enersyds rus die idee van 'n volkskerk of staatskerk op die gedagtegang. Dit begunstig ook die opvatting dat die sigbare kerkorganisasie nie belangrik is nie en tot ' $n$ ander orde behoort as die eintlike kerk van Christus. Die mense kan dus die kerk inrig soos dit 'n volk, staat of die mense in hulle omstandighede en opvattings die beste pas. Een van die vorme waarin hierdie proses van sekularisasie van die sigbare kerk hom voltrek het, word kollegialisme (A. Kuyper) genoem. 


\section{KOLLEGIALISTIESE INVLOED OP DIE KERKBEGRIP}

Eenvoudig voorgestel het die Rasionalisme veral in die 18 de eeu geleer dat mense hulle samelewingsverbande vorm op die basis van 'n wettige ooreenkoms (J. J. Rousseau e.a.). Elke mens is kragtens die natuurreg outonoom en gaan derhalwe so 'n kontrak tot staats-, kerk- of huweliksvorming vrywillig aan. Vir die doel mag hy sy gesag oordra aan ' $n$ verteenwoordiger om namens hom sy gesag uit te oefen. In die hoogste verteenwoordigende vergadering, kongres of konvensie setel daarom die hoogste gesag. Dmv 'n konstitusie word 'n liggaam in eie reg as regspersoonlikheid tot stand gebring. Gevolglik word daar gepraat van 'n kerkgenootskap waarby 'n mens kan aansluit of voor bedank. Dit bestaan as't ware objektief buite jou. Die begrip "lidmaatskap" waaroor in hierdie artikel gehandel word, hang m.i. onlosmaaklik saam met hierdie opvatting dat die kerk (algemeen of plaaslik) 'n genootskap of struktuur i.p.v. 'n gemeenskap van gelowiges is.

In dieselfde sin, wanneer die kerk as "genootskap" verstaan word, word gepraat van "die drie Afrikaanse Kerke" soos wat 'n mens drie soorte motorkarre byvoorbeeld sou kon kry wat jy teenoor mekaar kan opweeg. Dit maak nie so baie saak met watter een jy ry nie, jy kom met enigeen oor die pad.

In ' $n$ sekere sin by Rome en veral by die Reformatore het die kerk op aarde sigbaar geword waar die genademiddels (Woord en sakramente) bedien en ontvang is (vgl. art 28, 29 NGb). Die Rasiona. lisme verskuif die aandag nou totaal van die bediening as sentrale pool vir die institusionele karakter van die sigbare kerk, na die eenheid of struktuur wat op 'n kerkwet of kerkorde (as kontrak) gekonstitueer word. Ons kan sê dat die Rasionalisme die ministeriële kerkbegrip met, 'n kerksentriese of institusionele kerkbegrip verplaas het.

Volgens die gesagsbegrip van die Rasionalisme bepaal die meerderheid van die "lidmate" deur middel van hulle afgevaardigdes die organisasie of kerk. Sinodebesluite verleen dus aan die bepaalde kerkgenootskap sy besondere identiteit. Die Sinode bepaal die reëls en wie hom nie daarna skik nie, moet maar heengaan en elders tereg kom. Dit vorm 'n skril kontras bv. met art. $28 \mathrm{NGb}$ wat onttrekking van die ware kerk se bediening as sektevorming en 'n groot kwaad beskou.

Die Kollegialisme kan die gemeente nie as volledige en komplete kerk beskou nie maar soek die "sigbare eenheid van die Kerk" institusioneel (kerkordelik) in organisasie. Die woord kerk beteken miskien ten diepste iets soos "sinode" of "genootskap". Dit is 'n eenheid wat sigbaar vergestalt moet word in strukture. Die Ned. Geref. Kerk het vandag groot probleme met hierdie gedagtegange. Enersyds word geredeneer dat daar "een" NGK is en daarom een algemene sinode moet onderhou. Andersyds word gereken dat verskillende rasgroepe elk 'n eie sinode en daarom eie kerk het. Een sinode sou dan "een kerk" maak, wat volgens die verskeidenheid van rasse nie kan nie. 
Die kollegialisme reken ook gewoonlik dat die gemeente as verteenwoordiger van die oorkoepelende genootskap sinodebesluite moet nakom, omdat hy die identiteit van die genootskap waarvan hy lid is, moet weerspieël. Die kerkraad verteenwoordig in 'n sekere sin die gesag van die genootskap (sinode) by die "lidmate". Die kerkraad het so alles te sê en die gemeente het alles te gehoorsaam. Die gemeente is in baie opsigte die passiewe en die kerkraad die aktiewe gedeelte van die kerk. Om meer mense aktief te betrek, moet die kerkraad en "ampte" o.a. vir die vrou geopen word. Omdat vroue nie "ampte" beklee nie, is hulle passief en uitgesluit van "kerkwerk". Kragtens die kerksentriese i.p.v. bedieningsentriese benadering kan die "kerk met sinodebesluit oor die ampte besluit.

\section{DIE INDEPENDENTISTIESE BESKOUING}

Die Calvinistiese kerkgemeenskappe in Engeland (bv. Baptiste en Kongregasionaliste) het radikaal van bostaande verskil. Uit reaksie teen die Roomse en Anglikaanse hoog-kerklike beskouing wat die kerkeenheid in die sentrale gesag van die biskop of staat gesoek het, het die kongregasionaliste en baptiste geleer dat elke gemeente op homself staan en die ampsdraers is aan die lidmate verantwoording verskuldig. Die Bybel moet die enigste gesag dra. Die gemeentes kan konfereer, maar nie in sinode bindende besluite neem nie. Hulle het egter teenoor Rome en die Kollegialisme die kerk-wees by die gelowiges gesoek en in feitlik biblisistiese sin aan die Bybel in elke gemeente die enigste en hoogste gesag probeer gee. Die positiewe mo tiewe in hierdie stelsel is dikwels te maklik afgeskryf om kollegialisme te begunstig.

In ons eie kerkgeskiedenis tot ongeveer 1940, toe manne nog manne was en elkeen op sy eie bene kon staan, het plaaslike kerke hulle selfstandigheid teenoor klassisse en sinodes beskerm. Ons kerke is immers gebore toe mense gevra het teenoor kerkstrukture: Is het naar Gods Woord? Hulle het jaloers gewaak teen voorskrifte wat indring teen hulle reg om hulle eie huis in verantwoording aan God te regeer. Hulle het hulle nie deur dominees of sinodes laat oorheers nie.

Hierdie optrede staan lynreg teenoor die moderne voorliefde vir eenheidstrukture en eenvormigheid. Die begrip vir die verskeidenheid tussen plaaslike kerke mag nie met independentisme verwar word nie. Independentisme maak van 'n kerkraad 'n demokratiese instelling wat op demokratiese wyse aan die lidmate verslag moet doen. Dit bring die idee van "ons kerk" waar ons maak soos "ons wil" na vore.

\section{HOE STEL DIE BYBEL "KERK" AAN ONS VOOR?}

Ons woord "kerk" kom van die Grieks "kyriakon", (wat aan die Here behoort). Die woord kom nie in die Bybel voor nie. Die Bybel gebruik die woord "ekklesia" (eenheid van uitgeroeptes). Ons woord "kerk" moet dus vir ons sê, wat die Bybel met "ekklesia" sê. Die woord kom in twee betekenisse in die Bybel voor.

Talle kere, soos in Matthelis 16 en 18 beteken "gemeente" so veel 
as die gemeente of volk van God, die liggaam of bruid van Christus. In hierdie sin omvat "kerk" dan al die gelowiges wat waarlik en waaragtig en deur 'n ware geloof in Christus Jesus ingelyf is. Van die kerk bely ons: "Ek glo in EEN, heilige algemene Christelike kerk." Hierdie kerk kan per definisie net een kerk wees. Al praat ons van tien of duisend verskillende kerke, Christus het volgens die Skrif net een liggaam ( 1 Kor. 12; Ef. 1 en 4 ).

Ons bely in Artikel 27 van die Nederlandse Geloofsbelydenis:

"Ons glo en bely ' $n$ enige en katolieke of algemene kerk wat 'n heilige vergadering is van almal wat waarlik in Christus glo, wat hulle hele saligheid in Jesus Christus verwag en gewas is deur sy bloed, geheilig en verseël deur die Heilige Gees. Hierdie kerk was daar van die begin van die wêreld af en sal daar wees tot aan die einde toe, soos daaruit blyk dat Christus die ewige Koning is wat nie sonder onderdane kan wees nie. Hierdie heilige kerk word deur God bewaar en in stand gehou teen die woede van die hele werreld." Volgens die Bybel bely ons dus dat die gelowiges, mans, vroue en kinders, die gelowiges (en nie die ampsdraers of sinodes nie) die kerk is.

In die tweede plek praat die Bybel van die gemeente van Efose, gemeente van Antiochië, gemeente van Philadelphia, Smirna. Thiatire, ens. Tog beteken "kerk" ook hier die mense, die Christene, die mans, vroue en kinders wat op daardie plek 'n eenheid in hulle Here is. Die Bybel gebruik nooit die woord "kerk" vir 'n instelling, 'n abstrakte idee of regsnersoonlikheid, 'n organisasie buitekant die gelowige nie. Wanneer die eenheid tussen meer as een gemeente na vore kom. gebruik die Skrif die meervoud ,gemeentes". Die Skrif noem nooit soos die kollegialiste onder ons 'n eenheid van afsonderlike en verskillende gemeentes "kerk" nie.

Hierin tree 'n opvallende verskil tussen die drie Afrikaanse kerkgemeenskappe na vore. In die samesnrekings van die Interkerklike Kommissie het die NG en NH Kerke aanvaar dat die beorin kerk ook 'n eenheid van gemeentes aandui. Vir hulle het dje woord "kerk" twee betekenisse: eerstens 'n eenheid van mense, gelowiges in 'n gemeente (soos die Belydenis sê) en tweedens 'n struktuureenheid van institute of gemeentes in 'n kerkvergadering van ampsdraers (soos die Kollegialiste sê.)

\section{GOD SE EEN KERK EN ONS BAIE KERKE?}

Luther sê dat die kerk soos God dit ken tot die hemelryk behoort. Die kerk wat ons ken behoort tot die aardryk. Daarom maak kerkinrigting nie so veel saak nie, so lank die Woord gepreek word. Juis die feit dat die Skrif alleen en nie mense regeer nie (art. $7 \mathrm{NGb}$ ) maak die kerk 'n unieke instelling op aarde.

Ons bely in art. 28 NGB (wat ek met kommentaar tussen in hier weergee): "En ons glo dat. aangesien hierdie heilige vergadering aie katolieke kerk) ' $n$ versameling is van die wat verlos word en daar buitekant, (buitekant die katolieke kerk, die liggaam van Christus) geen saligheid is nie, niemand, van watter stand of waardigheid ook 
al, hom daaraan behoort te onttrek om op sy eie te bestaan nie, maar dat hulle almal verplig is om hulle daarby aan te sluit en hulle daarmee te verenig, om die eenheid van die kerk te bewaar, om hulleself te onderwerp aan sy leer en tug (nie die Gereformeerde Kerk se leer en tug nie, maar die Heilige Algemene Kerk se leer en tug) hulle nek te buig (nie onder die sinodebesluite of kerkraadsbesluite nie), onder die juk van Jesus Christus en as lede van dieselfde liggaam onderling diensbaar te wees aan die opbouing van die broeders volgens die gawes wat God hulle gegee het. En om dit des te beter te onderhou, is die amp van die gelowiges (nie van die predikant of die ouderlinge nie maar van die gelowiges) volgens die Woord van God om hulle af te skei van diegene wat nie tot die kerk behoort nie en hulle te voeg by hierdie vergadering, op watter plek God dit ook al gevestig het, ook al sou owerhede en verordeninge en soewereine vorste daarteen wees."

In die volgende artikel bely ons dat die kerke van God op aarde aanwesig en kenbaar is waar die Woord bedien en gehoorsaam, die sakramente bedien word soos Christus dit ingestel het en die tug van die Woord oor die kerk gaan (NGb 29). Die Belydenis benadruk dus die aktiwiteit en verantwoordelikheid van elke gelowige om die plaaslike kerk te beoordeel.

Die plaaslike kerk, eenheid van gelowiges, is dus die een heilige algemene kerk van Christus op daardie plek. Ons baie kerke (gemeentes) is aan mekaar verbonde in die een kerk van God in so ver ons aan die Woord gehoorsaam is en daarvolgens lewe.

Die een-wees van baie kerke word nie deur organisasie of sinodes bepaal en vergestalt nie - maar deur die mate waarin elke plaas. like kerk die een kerk van God vergestalt en sigbaar maak.

\section{HOE KEN ONS GOD SE EEN KERK IN DIE SIGBARE KERK?}

Ons weet (art. $29 \mathrm{NGb)}$ dat ware gelowiges en huigelaars kan in 'n gemeente vermeng wees, maar die ware kerk word gevind waar die Evangelie suiwer gepreek, die sakramente suiwer bedien word, soos Christus dit ingestel het en waar sondes kerklik getug word. Kort gesê: almal moet hulle gedra ooreenkomstig die suiwere Woord van God (nie volgens kerkraadsbesluite nie) en alles verwerp wat dáárteen stry. Die kerk word aan God se Woord gemeet, waar gepreek, sakramente bedien en gelewe word. Die ware of valse gestaltes van die kerk word in en by die mense wat die gemeente is, gesien en nie in strukture vasgelê, sodat ons kan sê hierdie gemeenskap van kerke is ware en daardie valse kerke nie. Nee, by kerke in dieselfde sinodale verband kan een gemeente die tekens van ' $n$ valse kerk openbaar bv. wanneer hulle sonde beskerm.

Die NGb vervolg dat ons Jesus Christus moet erken as die enigste hoof van die gemeente (kerk) (art. 31): nie die pous nie, nie die dominee en Christus nie, nie die kerkraad en Christus nie en ook nie die sinode nie. Christus is die enigste hoof van die ware kerk wat in die eenheid van gelowiges in die gemeente sigbaar word. Niemand mag hom van hierdie ware kerk afskei nie.

Ons Belydenis volg hier Calvyn se kerkbegrip. Calvyn was 'n 
regsgeleerde. $\mathrm{Hy}$ was uitnemend in staat om 'n pragtige "gereformeerde" konstitusie of grondwet vir 'n kerk op te trek, indien die kerk in die instituut vergestalt moes word. Calvyn het egter na die Skrif gegaan en gesê die kerk is daar waar die Woord van God suiwer gepreek en gehoorsaam word, die sakramente bedien en ontvang word soos Christus dit ingestel en volgens die Woord gelecf word. Die een ware kerk van God word nêrens duideliker as aan 'n Nagmaaltafel sigbaar nie.

As Calvyn daarvan beskuldig word dat hy van die tradisionele kerkinstituut en so van God se kerk afgeskei het, dan sê hy: "Maar hoe kan dit wees? Hoe kan ek, wat die Woord van God probcer gehoorsaam, van die kerk weg wees, en julle, wat die Woord van God verwerp, nog kerk wees?"

Hierdie verhouding: nader aan en weg van die Woord van God bepaal watter mens en watter kerk waarlik kerk en wie nie van God se kerk is nie.

Die kerk is ' $n$ wonder. Dit rus in God se verkiesing. God gee geloof, want die Woord word gepreek, maar nie almal ontvang dit nie. Daar waar die Gees korreleer met die Woord, daar kry jy geloof. Geloof bind saam. So word 'n mens ingelyf, sê die Doopformulier, in die liggaam van Christus (die kerk). Die doop is die sakrament van die universele kerk. Daardie gelowiges kom saam, soos wat dit fisies moontlik is, op ' $n$ bepaalde plek in die tyd rondom hierdie Woord en die Nagmaal is by uitstek die plek waar jy die kerk sien.

Om kort saam te vat: die plaaslike kerk, die gemeente, is die universele kerk op daardie plek. Die eenheid in Christus van die katolieke (d.w.s. algemene) kerk kan nêrens anders gesien word as in die eenheid van broeders en susters, mans, vroue en kinders, wat in die plaaslike kerk saamkom nie. Die gemeente is daarom primêr ware of valse kerk volgens art. $29 \mathrm{NGb}$. Daaroor moet elke gelowige met die Bybel in die hand oordeel en dit uitmaak (art. 28 NGb).

\section{GEREFORMEERDE KERKINRIGTING BEGIN MET ORDE - NIE KONSTITUSIE NIE.}

Die kerk is primêr nuwe gemeenskap, lewende organisme eenheid van verlostes, vergadering van gelowiges. Calvyn sê die kerk is nuwe ware orde. Hierdie orde bring noodwendig mee dat die liggaam (gemeente) op ' $n$ bepaalde manier georganiseer, saamgestel is. Die institusionele staan dus in diens van die kerk as volk van God.

Die Gereformeerde kerkbegrip verskil dus radikaal van die Roomse wat met die instelling van die amp of die kollegialisme wat met die grondwet of konstitusie van die genootskap, die sinode, begin. Dink daar goed oor na. Die kollegialiste begin met 'n "verteenwoordigende" vergadering (sinode). Die "hoogste liggaam" of "kerk" stel dan 'n konstitusie (kerkwet- of kerkorie) op. Daarvolgens word die kerk ingerig. Die instituut bepaal die kerk.

Totaal anders het Calvyn, hoewel hy geskoolde juris was, te werk gegaan. God roep en maak die kerk met sy Woord en Gees (art. 27 NGb). Dit moet eers verkondig word. Die gelowiges kom saam. Die Here roep en gebruik hulle om opsieners daar te stel. Daarmee is 
die kerk ingestel en georganiseer. Calvyn gee daarom in Genéve 1537 net orde artikels wat die dienste van die predikers reël. Die hele kerkinrigting en kerkorganisasie is gerig en gebou op die diens van die Woord. Wanneer die Woord wat die Gees gebruik, gebring en gehoorsaam word, is daar 'n kerk georganiseer. Die Woord skep orde en daardie orde is die kerk.

Elke plaaslike gemeente is selfstandig en volledig kerk. Elke gemeente is egter nie selfgenoegsaam en alleen (independent) kerk nie. Elke ware gemeente openbaar juis die liggaam van Jesus Christus, die een kerk. Die gemeentes is dus so naby familie van mekaar soos wat familie maar kan wees. Hulle is een in Christus, een in geloof, een in doop; hulle het een God en Vader (Ef. 4).

Die eenheid van die gemeentes kom in die eerste plek uit in wat hierdie mense antwoord op die Woord van God, hulle Belydenis.

Tweedens kom dit uit in die lewe van die gelowiges dinge wat hulle doen. Gelowiges se "doen" word "diens" genoem. In ware kerk-wees dien die gelowiges eerstens die Here en daarom dien die broeders en susters mekaar ook onderling "in die Here". Predikante, ouderlinge en diakens dien die liggaam wat die gelowiges is, sodat hulle des te beter hulle diens na Bo en na buite kan volvoer. Die gelowiges doen by uitstek saam in liturgie en wat daarmee saamgaan. Hulle is so naby familie deur die geloof dat hulle mekaar broeder en suster noem. Tug waar liefde heers, begin met onderlinge toesig (Matt. 18) van mondige gelowiges.

Die eenheid of intieme familieskap van die selfstandige kerke (gemeentes) bring mee dat die kerke ook in 'n kerkverband, 'n hegte familieverband, 'n geloofsverband, 'n koinonia in Christus staan. Kragtens hierdie eenheid wat hulle gesamentlik het en waarvan hulle elkeen ' $n$ beeld is (die heilig algemene Christelike kerk), is hulle geroep om in leer en lewe by die Woord van God te bly. Daarom en daartoe moet hulle mekaar ook help. Kragtens hierdie eenheid kry ons baie vorme van saamlewe, saamwerk en onderlinge hulp in en tussen die kerke - (bv. in kerkregering deur onderlinge attestering, Rom. 16 vir Phoebe; advies van naburige kerke, Hand. 15; besluite van kerke in klassis of sinode waar hulle, let wel, as kerke saamkom, diakonale hulp ens).

Hierdie eenheid kom veral uit in ware kerkregering waar kerke mekaar help om die Woord van God te bewaar in suiwer Belydenis, die Woord toe te pas en geloofslewe uit te bou soos dit in elke tyd en vir elke nuwe probleem nodig is.

Die sinode is nie 'n nuwe struktuur naas die kerke (gemeentes) nie. Dit is ' $n$ byeenkoms van verskillende plurale regspersoonlikhede: selfstandige kerke. Soos wat Calvyn artikels gegee het om die dienste te reël, so het die kerke ook artikels aanvaar om die samekomste tussen hulle moontlik te maak. Hierdie Kerkorde is die basis waarop sinodes ('n klassis is ook 'n sinode) besluite kan neem. Die Kerkorde is dus nie 'n blote sinodebesluit nie en allermins 'n sinodevoorskrif of kerkwet. Die Kerkorde maak dus nie 'n kerk-as-sinode nie, maar is die wettige afspraak van kerke in kerkverband (korre- 
spondensie of koinonia) waardeur sinodale samekomste (en nie strukture nie) daargestel word.

Die gedagte dat die sinode of die klassis "die kerkverband" is, vind in die Skrif nie steun nie. Samekomste en samewerking van kerke in sinodes is moontlik omdat daar kerkverband in Christus gegee is. Kerkverband gaan aan sinodes vooraf. Kerke help mekaar op baie maniere. Die maniere word nie in konstitusie of kerkwet voorgeskryf nie. Dit word deur die kerke self volgens behoeftes bepaal. In kombinasies staan twee kerke saam en beroep een predikant wat dieselfde diens by albei gaan doen of hulle pak sending of evangelisasie saam aan. Hulle lê as kerke saam in die loopgrawe vir die Koninkryk van God.

\section{VRAAGTEKENS AGTER DIE BEGRIP "KERKLIDMAATSKAP".}

$U$ het my gevra om te handel oor kerkbegrip en "kerklidmaatskap". Indien ek geslaag het, moet ons nou kan vasstel: God roep dienaars om die Woord te preek en Hy (die Gees) gee geloof; die gelowiges kom saam rondom die genademiddelle en so kry die kerl as volk van God institusionele gestalte. Dit beteken logies dat gelowiges eerder en voor die "kerk" is. "Kerklidmaatskap" laat my dink aan 'n kerk wat eerder en voor die gelowiges is, waarby hulle kan gaan aansluit of waar van hulle kan afskei, soos die geval met 'n politieke party is. Die kerk as instelling staan staties buitekant die gelowige en jy kry deur lidmaatskap, soos in ons partyorganisasies deel aan die instituut.

Ons moet weet dat ons vandag in spoor met die tyd die kerkvraag eerder as die geloofsvraag of Skrifvraag stel. Ek dink die meeste gevalle waar van "kerklidmaatskap" gepraat word die kerk as statiese strukture die geloofsvraag en Skrifvraag as vertrekpunt verplaas het. Dit het 'n sterk sekulêre klank.

My beswaar teen die begrip "kerklidmaatskap" is dat jy ligtelik daarmee die mens, die gelowige, bekyk vanuit die gesigspunt van die kerk as sigbare instelling. Die lewende gelowige moet dan aanpas aan en inpas by die organisasie, die formele struktuur. Dit verplaas prioriteite. Volgens die Skrif is die gelowiges primêr lede van die liggaam van Christus. Die kerkorganisasie wat eintlik s!egs die "dienste" of ampte behels, is daar tot diens van die gelowiges (Ef. 4). Wanneer die kerkorganisasie so belangrik word en gelowiges daaraan diensbaar moet wees, het die orde wat die Skrif leer, omgekeer.

Die moderne sosiologie noem hierdie kwaal as institusionalisme. Mense skep 'n organisasie om 'n sekere diens te lewer. Gaandeweg vra die organisie al meer aandag, energie en finansies vir homself onder voorwendsel dat hy dan meer en beter sal werk. Gewoonlik slurp die organisasie (instituut) geleidelik alles op en bly diens na buite, die oorspronklike doelstelling, maar beskeie gering.

Die wese van die algemeen heilige kerk is organies (1 Kor. 12). 'n Mens is lid van 'n kerk - natuurlik op sy unieke wyse - soos jy lid is van 'n volk. Jy kan praat van jou lidmaatskap. Per slot van rekening moet jy met jou lewe, liefde, geloof bewys of jy lid is. Om 
lid te wees is nie dieselfde as lidmaatskap nie. Dit is nie iets formeels nie. Dit kom neer op daadwerklik in leer één wees (vandaar Formuliere van eenheid).

In die tweede plek moet wat ons glo $00 \mathrm{k}$ werklik bevestig word met 'n lewe wat in elke opsig die toets van die Woord van God kan deurstaan. Wanneer ons lewe die lig van die Woord van God nie kan vat nie, mag ons aanspraak op "lidmaatskap" maak, terwyl ons weg van die kerk leef. Die liggaam van Christus kom dan met vermaning, tugoefening en uiteindelik selfs sensuur in spanning om die lidwees te herstel of te konstateer ( 1 Kor. 5 en 12).

Die gelowige is dus lid van die kerk in so ver hy bely en leef volgens die Woord van God. Daar is niks meer nodig om te bewys dat die gelowige lid is van die kerk nie. Die lid-wees kom in gedrang by die weg wees van die Woord van God in leer of in lewe. Daarom attesteer kerke oor die leer en lewe van mense wanneer hulle elders hulle by die kerk voeg.

\section{'N GEREFORMEERDE IS MONDIG}

Die groot beginsel van die Hervorming was die mondigheid van die gelowige. Die gelowige het nie 'n pater of 'n dominee nodig om vir hom pa te staan nie. Volgens die Skrif begin die ware kerkregering, die tug, by die individu. 'n Gesonde liggaam reageer self teen die kwaad (Matt. 18:15v). Daarna gaan dit oor na die geroepe ouderlinge wat afsonderlik en gesamentlik die meervoud in (Hand. 20) toesig hou. Die ouderling het geen reg om in beroep op sy amp oor mense te heers nie.

Die woord "amp" kom ook nie in die Bybel voor nie. In Hebreërs is daar een plek waar van 'n hoëpriester se waardigheid gepraat word. Die Bybel praat nie van "ampsdraers" (hoogwaardigheidsbekleders) nie, maar van "dienaars". 'n Voorganger word "opsiener", "herder" "diaken," "leraar" "evangelis" genoem. Geen dominee of ouderling beklee 'n posisie op sterkte waarvan hy heerskappy oor 'n lidmaat mag uitoefen nie.

'N GEREFORMEERDE IS WARS VAN MENSLIKE HEERSKAPPY IN DIE KERK

Die heel eerste sinode, die Sinode van Emden 1571 stel in Artikel 1 as uitgangspunt: geen kerk sal oor 'n ander kerk, geen dienaar oor 'n ander dienaar, geen ouderling oor 'n ouderling of 'n diaken oor 'n diaken enige heerskappy voer nie.

Let op wat ons bely in Artt. 31 en $32 \mathrm{NGb}$. wanneer ons reëls by wat God in sy Woord vir ons gegee het, maak, mag ons nie daarmee mense dwing of in hulle gewetens bind nie. Die mondige gelowige mens het vryheid en reg in middelmatige sake, d.w.s. sake waaroor God se Woord nie 'n uitspraak doen nie. Ons moet erken dat ons dikwels met 'n beroep op "orde", of met eenvormigheid of op sterkte van sinodepatrone grootliks die gelowiges stemloos, stom en regloos gemaak het.

Christus is die enigste hoof. Daarom kan dié mense wat Hom aan die gelowige bedien niks anders as dienaars, tafelbediendes, 
wees wat die Woord opskep sodat ander dit kan eet nie. Die oomblik wat 'n dienaar baas word en in die kerk heers, word die gelykenis van die landbouers (Luk. 20) werklikheid. Dan maak die dienaars hulle meester van die wingerd van God.

Die Skrif lê geweldig nadruk op persoonlike verantwoordelikheid en geloof. Die lidmaat in Christus is vrygemaak. Hy moet hom nie weer onder 'n juk van diensbaarheid laat bring nie (Gal. 5). Iemand in die kerk kan dus slegs gedwing word as dit op die Woord van God gegrond is.

Artikel $29 \mathrm{NGb}$ se daarom die valse kerk kan maklik uitgeken word: "Die valse kerk skryf aan homself en aan sy ordinansies (d.w.s. sy wil en besluite) meer mag en gesag toe as aan die Woord van God en wil hom aan die juk van Christus nie onderwerp nie. Dit bedien die sakramente nie soos Christus dit verorden het nie; neem daarvan af, voeg daaraan toe na sy goeddunke. Dit steun meer op mense as op Christus, vervolg diegene wat heilig lewe na die Woord van God en die kerk oor sy gebreke, gierigheid en afgoderye bestraf."

Die gelowige moet hom by die gemeente voeg.

In Artikel $28 \mathrm{NGb}$ bely die Gereformeerde sy plig om hom by die kerk te voeg. Hiermee hang twee beginsels saam.

Die eerste beginsel: 'n Gelowige moet hom by die ware kerk voeg. Die lidmaat moet die kerk oordeel. Gewoonlik is dan gewys op die Gereformeerde Kerk in Suid-Afrika, die Belydenis, Liturgie en Kerkorde (dikwels 'n gearriveerdheid met verwysing na die dokumente. die papier); die predikante vertel nie storietjies nie, ens.

Elkeen is dus verplig om hom by "die kerk" (kerkgenootskap?) te voeg.

Dit is egter nie die kerk waarvan Artikel 28 praat nie. Ons bely die kerk "op watter plek God dit ookal gevestig het". Dit is die plaaslike kerk.

'n Gereformeerde gemeente kan die valse kerk op 'n plek wees, as daar nie suiwer gepreek word nie, tug bedien word nie en mense daar in die plek van die Woord van God gesag voer. Die verhouding tot die Skrif en nie die verhouding tot 'n instelling nie, byvoorbeeld 'n sogenaamde Gereformeerde Kerk in Suid-Afrika bepaal of die kerk waar of vals is. Die gelowige moet dus oor die leer, lewe en doen van die plaaslike kerk oordeel.

Die tweede beginsel: die lidmaat moet hom voeg. Dit beteken dat die lidmaat primêr verantwoordelikheid dra. Hy moet vrae vra, kles en beslis: Die beslissende is: Waar kry ek die Woord van God? In die lig van die antwoord moet hy hom by 'n gemeente voeg. Hy ontvang daarvoor 'n attestaat wat hy moet indien waar die beeld van die kerk van Christus in 'n plaaslike kerk sigbaar word.

\section{MAG DIE LIDMAAT OOK OOR KERKE IN DIESELFDE KERKVER- BAND OORDEEL?}

Dit is ' $n$ moeilike en gevoelige vraag. Die probleem kom gewoonlik as 'n grenskwessie na vore. Grense word by afstigting gereël en deur die kerke in 'n klassis goedgekeur. Wat is die gesag van so 'n grensreëling? Is dit adviserend of is dit absoluut bindend? 
'n Voorbeeld: Lidmaat A val in Kerk X, maar sy hele lewe sentreer rondom die gebied waarin kerk $\mathrm{Z}$ is. Waarom mót hy nou by kerk $\mathrm{X}$ en mag hy nie by $\mathrm{Z}$ nie? Mag hy gedwing word om by kerk $\mathrm{X}$ te wees omdat "grense" so vasgestel is? Het hy geen reg of verantwoordelikheid nie? Is die grens belangriker as die mens? Die antwoord is gewoonlik: daar moet orde wees. Moet die mens die orde dien of die orde mense dien?

Vergelyk 'n tweede, miskien moeiliker probleem. Lidmaat B woon in 'n gebied wat toegewys is aan kerk $O$, maar die tipe en vorm van prediking spreek glad nie aan nie. Daar is nie moeilikheid nie, maar ook nie kommunikasie nie. Die kategese in daardie kerk is blou-blou, sommer Sondagmôre gou-gou. Die mense word nie gestig nie. Niemand kan eintlik 'n klag lê nie. Baie is tevrede. Een swaeltjie kan nie somer maak nie.

Miskien is die prediker rasioneel ingestel en die lidmaat het behoefte aan meer warmte. Hier digby hom, maar anderkant die "grens" kan hy die woord kry in die vorm wat hom bevredig. Moet hy nou week na week, jaar na jaar binne die "grense" bly, al verkwyn en verdor hy? Moet hy geestelik doodgaan om 'n blote ordereëling soos ' $n$ grens te eerbiedig? Is dit kerk? Is dit saamlewe? Indien ons uitspraak gee, op watter gesag doen ons dit?

Waarom opereer so baie kerkrade met 'n statiese en meganiese kerkbegrip wat eenvoudig op grense baseer is? Waarom hoor 'n mens nie dat die lidmaat ook pligte en regte het om te sê by watter kerk hy hom wil voeg nie? Die regte en pligte van lidmate om te kies, word gewoonlik weggeneem met die vraag: Wat dan van die orde?

Wanorde kan per definisie nooit kerk wees nie.

Orde is iets wat gereël word. Ek beweer nie dat dit aan 'n lidmaat alleen kan oorgelaat word om te maak soos hy wil nie. Maar dieselfde Skrif - en ordebeginsel sê ook dat kerkraad X nie alleen met beroep op "grense" mag besluit en reël nie. In hierdie geval is daar minstens drie partye wat volgens die Skrif in liefde moet onderhandel en nie vir hierdie taak agter 'n wet of "grens" mag wegkruip nie: eerstens die lidmaat wat hom moet voeg, tweedens die kerk wat kerklike grensreëlings vir hom aanwys en derdens die kerk waar hy hom wens te voeg. Wanneer hierdie drie instansies saam op die saak ingaan en die een die ander soos die Skrif sê uitnemender ag as homself, moet daar 'n menslike en Bybelse oplossing kom. Ons moet met mekaar praat, nie elkeen na sy eie belange omsien nie en die ander uitnemender ag as jouself. Drie moet die saak op meriete oplos, nie een nie en allermins 'n beroep op 'n dooie "grens" - of die finansies van die kerk doen. In 'n besluit oor waar iemand lid in die kerk van die Here moet wees, mag nie afgedoen word met: die klassis het grense "vasgestel" nie. Indien wel, is die dood in die pot en loop ons die pad van Rome en die kollegialisme. Indien die lidmaat vir kerk $\mathrm{Z}$ kies en laasgenoemde is bereid om hom te ontvang, waarom sou kerk $X$ weier? Terwille van sy eie belange? Is die lidmaat dan daar om kerk $X$ te dien of is die kerklike dienste ingestel om die lidmate te dien en op te bou? Soms word gesê "grense" moet gehandhaaf word" anders gaan die kerk $\mathrm{X}$ doodbloei in $\mathrm{Z}$ in. Die 
rede word soms gesoek in die beperking van die dominee in X. Kan ons die kerk terwille van dominees organiseer? Is dominee-diens 'n vorm van beskutte-arbeid? Indien ons nie met geestelike middels soos oorleg, inligting, aandrang en pleit kerk $\mathrm{X}$ kan bewaar nie, mag ons dit kunsmatig met meganiese grensbepalinge doen? Is dit nie naakte institusionalisme nie?

\section{NIE INSTITUUT-WEES NIE MAAR MONDIG-WEES VOOROP!}

Indien ons kerkbegrip uitgaan van 'n "kerk" wat as instituut en organisasie oor 'n sekere vaste geografiese terrein vasstaan en meganies mense indeel, het die instituut as sigbare kerk doel op homself geword.

Die Skrif en die Belydenis roep 'n gelowige op om mondig te wees. Elke gelowige moet in staat wees om die Woord van God in sy lidmaat-wees en in sy kerk-wees te hanteer. Hy is nie in die kerk nie, maar hy is self lid van die liggaam, kerk. Om kerk te wees, moet ons orde handhaaf. Dié orde word egter nie bepaal deur wat die kerkof die sinode voorskryf nie, maar deur die verhouding tot die Woord van God. Waar prediking, sakramente, tug, kategese en veral die lees en wandel van die gelowiges met die Woord ooreenkom, daar is orde. In daardie orde is die kerk sigbaar.

Ten diepste, as ons kan wegkom van die Westerse, Romeinsregtelike, institusionele kerkbegrippe en weer kom tot 'n kerk wat lewe rondom die Woord van God, dan roep dit ons op tot verantwoordelikheid aan God. Die woord "verantwoordelikheid" impliseer dat ons onder verligting van die Heilige Gees moet antwoord op die Woord van God. Dan gaan dit ten diepste nie om lidmaatskap van gemeente $\mathrm{X}$ nie, maar om in ware kinderlike geloof waaragtig lid te wees van die liggaam van ons Here Jesus Christus.

(Enkele jare gelede gelewer te Verwoerdburg-Noord). 